\title{
Editorial
}

\section{The East in the West}

\author{
Francisco Baldaque-Silva
}

Endoscopy Unit, Department of Upper Abdominal Diseases, Karolinska University Hospital and Karolinska Institute, Stockholm, Sweden

\section{Keywords}

Endoscopic submucosal dissection - ESD - Gastrointestinal tract

\section{O Oriente no Ocidente}

\section{Palavras Chave}

Dissecção endoscópica da submucosa · ESD · Tracto gastrointestinal

Endoscopic submucosal dissection (ESD) is a technique developed in Japan for the resection of early gastric lesions that is increasingly used for the removal of superficial neoplasias along the gastrointestinal tract. Contrary to endoscopic mucosal resection, ESD allows en bloc resection of lesions $>2 \mathrm{~cm}$, enabling proper pathological assessment. ESD is associated with increased curative rates and reduced recurrence rates, but it is more often complicated with perforation, most of these cases being managed endoscopically. Both techniques have similar bleeding complication rates [1].

In this issue of GE - Portuguese Journal of Gastroenterology, Costa et al. [2] report on the results of 114 gastric

\section{KARGER}

E-Mail karger@karger.com www.karger.com/pjg
(C) 2018 Sociedade Portuguesa de Gastrenterologia Published by S. Karger AG, Basel

Karcer

Open access

This article is licensed under the Creative Commons AttributionNonCommercial-NoDerivatives 4.0 International License (CC BYNC-ND) (http://www.karger.com/Services/OpenAccessLicense). Usage and distribution for commercial purposes as well as any distribution of modified material requires written permission.
ESDs performed in a high-volume center in Portugal. Authors found that gastric ESD is associated with en bloc resection in $96 \%$ of all cases, corresponding to R0 resections in $88 \%$, a curative resection was obtained in $83.2 \%$. These excellent results are re-enforced by the fact that the disease-specific survival rate at 12 months was $100 \%$. In this study, most R1 resections were associated with positive lateral margins. That may be explained by the difficulty in delineating lesions in the stomach, where changes in the background mucosa are frequently present, but it may also be associated with the lesion's characteristics, the nature of the endoscope used, and the ESD technique. All these parameters are prone to improvement. Early detection and proper delineation may be improved not only with the use of high-resolution endoscopes, but also by virtual or conventional chromoendoscopy. This requires optimal equipment and good endoscopic assessment and characterization skills. This work has been developed by several Portuguese gastroenterologists during the last years [3-8]. The improvement in $\mathrm{R} 0$ resection rates in the study by Costa et al. [2] may reflect improvements in all these factors.

In this study, complications occurred in $13.2 \%$ of all ESD procedures. This figure is slightly higher than that in 
most recent reports, but it reflects the learning curve process. The fact that all major complications were managed endoscopically reflects on the technique's safety per se, on the skillful endoscopist engaged in this study, and on the close follow-up of patients by a multidisciplinary team that enabled proper and successful treatment of complications.

\section{What May Be Expected in the Future?}

Contrary to what happens in the rest of Europe and North America, there is a relatively high rate of gastric cancer and of early gastric lesions in Portugal [9]. Early gastric lesions are more prone to ESD resection due to the efficacy and safety of the technique in the stomach. In fact, the stomach is the organ used in the learning process of ESD - not only in experimental models but also in the clinical setting. In most countries in Europe and North America, the lack of early gastric lesions hampers the development of gastrointestinal ESD expertise by the fact that colonic ESD demands higher expertise and is associated with higher complication rates. So, Portugal is in the privileged situation to lead the development of gastrointestinal ESD in the West. It is expected that the good results of different Portuguese centers in gastric ESD cases will soon lead to the implementation of ESD in esophageal and colorectal superficial lesions. Portugal may be the new frontier in the development of ESD and of other advanced endoscopic techniques in the West [10]. That may be accomplished by a centralization of ESDs in highvolume centers and by a collaboration between different hospitals in order to establish the new standards on ESD in the West and to promote the development of new advanced techniques.

The future is bright!

\section{Disclosure Statement}

Author reports no disclosures related to this article.

\section{References}

1 Odagiri $\mathrm{H}$, Yasunaga $\mathrm{H}$ : Complications following endoscopic submucosal dissection for gastric, esophageal, and colorectal cancer: a review of studies based on nationwide largescale databases. Ann Transl Med 2017;5:189.

2 Costa RS, Ferreira A, Leal T, Costa D, Rolanda C, Gonçalves R: Endoscopic submucosal dissection for the treatment of superficial epithelial gastric neoplasia in a Portuguese centre. GE Port J Gastroenterol 2018; Doi 10.1159/000487820.

3 Dinis-Ribeiro $M$, Areia $M$, de Vries AC, Marcos-Pinto R, Monteiro-Soares M, O’Connor A, Pereira C, Pimentel-Nunes P, Correia R, Ensari A, Dumonceau JM, Machado JC, Macedo G, Malfertheiner P, Matysiak-Budnik T, Megraud F, Miki K, O'Morain C, Peek RM, Ponchon T, Ristimaki A, Rembacken B, Carneiro F, Kuipers EJ; European Society of Gastrointestinal Endoscopy; European Helicobacter Study Group; European Society of Pathology; Sociedade Portuguesa de Endoscopia Digestiva: Management of precancerous conditions and lesions in the stomach (MAPS): guideline from the European Society of Gastrointestinal Endoscopy (ESGE), European Helicobacter Study Group (EHSG), European Society of Pathology (ESP), and the Sociedade Portuguesa de Endoscopia Digestiva (SPED). Endoscopy 2012;44:74-94.

4 Buxbaum JL, Buxbaum JL, Hormozdi D, Dinis-Ribeiro M, Lane C, Dias-Silva D, Sahakian A, Jayaram P, Pimentel-Nunes P, Shue D, Pepper M, Cho D, Laine L: Narrow-band imaging versus white light versus mapping biopsy for gastric intestinal metaplasia: a prospective blinded trial. Gastrointest Endosc 2017;86:857-865.

5 Silva FB, Silva FB, Dinis-Ribeiro M, Vieth M, Rabenstein T, Goda K, Kiesslich R, Haringsma J, Edebo A, Toth E, Soares J, Areia M, Lundell L, Marschall HU: Endoscopic assessment and grading of Barrett's esophagus using magnification endoscopy and narrow-band imaging: accuracy and interobserver agreement of different classification systems (with videos). Gastrointest Endosc 2011;73:7-14.
6 Rodrigues J, Carmo J, Carvalho L, Barreiro P, Chagas C: Endoscopic submucosal dissection for gastrointestinal superficial lesions: initial experience in a single Portuguese center. GE Port J Gastroenterol 2015;22:190-197.

7 Pimentel-Nunes P, Libanio D, Dinis-Ribeiro $\mathrm{M}$ : Evaluation and management of gastric superficial neoplastic lesions. GE Port J Gastroenterol 2017;24:8-21.

8 Libânio D, Pimentel-Nunes P, Afonso LP, Henrique R, Dinis-Ribeiro M: Long-term outcomes of gastric endoscopic submucosal dissection: focus on metachronous and noncurative resection management. GE Port J Gastroenterol 2017;24:31-39.

9 Areia M, Spaander MC, Kuipers EJ, Dinis-Ribeiro M: Endoscopic screening for gastric cancer: a cost-utility analysis for countries with an intermediate gastric cancer risk. United European Gastroenterol J 2018;6:192-202.

10 Baldaque-Silva F, Marques M, Vilas-Boas F, Maia JD, Sá F, Macedo G: New transillumination auxiliary technique for peroral endoscopic myotomy. Gastrointest Endosc 2014;79:544-545. 